\title{
THE IMPORTANCE OF USING DIFFERENT METHODS OF ANALYSIS IN DEALING WITH THE CHALLENGES OF COLLUSIVE TENDERING AND OTHER FORMS OF CORRUPTION IN THE SOUTH AFRICAN PUBLIC PROCUREMENT SYSTEM
}

\author{
Tebogo Makube
}

\section{(2019) 6 APPLJ 42}

\begin{abstract}
This study reviews and examines policy, legislative and institutional frameworks dealing with collusive tendering or bid-rigging as an anti-competitive behaviour and practice in the South African public procurement system. A competitive public procurement system is a constitutional mandate and requirement in South Africa; therefore, the well-functioning government and delivery of services are vital for growth, development and social welfare in any country. The devolution of procurement function assumes that all organs of state have the capability and capacity to detect and prevent anticompetitive behaviour and practices. A postulation is made in this study that public procurement regulations and rules in South Africa are not robust enough on measures to detect and safeguard against bid-rigging and collusive behaviour. Concomitant corruption elements such as the manipulation of the bid specifications, designs, industry and technical standards, and technological choices are also used as tools to undermine competition and aid certain bidders.
\end{abstract}

While competition policy and law are critical in combating the scourge of collusive conduct in the public sector markets, an effective approach involves reforms to the public procurement systems itself. This study advocates for the usage of different methods of analysis in dealing with the challenges of collusive tendering and other forms of corruption in the South African public procurement system. This will require a review of policies, legislation and institutions dealing public procurement and competition. 


\section{THE IMPORTANCE OF USING DIFFERENT}

METHODS OF ANALYSIS IN DEALING WITH

THE CHALLENGES OF COLLUSIVE

TENDERING AND OTHER FORMS OF

CORRUPTION IN THE SOUTH AFRICAN

PUBLIC PROCUREMENT SYSTEM

\section{Tebogo Makube}

B.Admin (Hons), LLB, MSc (Energy Economics), MPhil (Economic Policy), LLM (Public Procurement Law), PhD (Energy Studies), Post.Grad.Cert (Competition Law)

Chief Director: Industrial Procurement at the Department of Trade, Industry \& Competition, South Africa

\section{Introduction}

This study reviews and examines policy, legislative and institutional frameworks dealing with collusive tendering or bid-rigging as an anti-competitive behaviour and practice in the South African public procurement system. Other forms of corruption in public procurement are alluded to but do not form the purview of this study. Collusion, which is an agreement ${ }^{1}$ concluded between parties that are either in competition with each other or are not necessarily competitors in the same market, thereby constituting a down or upstream amalgamation of resources. ${ }^{2}$ In bid rigging, competitors secretly agree not to compete for certain products, customers or in certain geographic areas. ${ }^{3}$ Cartel activities are regarded as the most serious of all competition law

\footnotetext{
*I would like to thank Prof Geo Quinot of Stellenbosch University for his helpful comments on an earlier draft of this article. Views expressed in this article are solely my own and not those of my employer.

1 Section 1(1)(i) of the Competition Act (Act No. 89 of 1998) defines an agreement to include 'a contract, arrangement or understanding, whether or not legally enforceable.

2 Campell 2011.

3 OECD 2016.
} 
contraventions. ${ }^{4}$ The standard bid rigging behaviour involves potential bidders agreeing amongst themselves to collude and coordinate their bids in order to determine the winner at a particular price. In essence, collusion seeks to prevent, restrict or distort competition by the sharing of markets and customers. ${ }^{5}$

The South African Competition Act (Act No. 89 of 1998), as amended, ("the Act") regards restrictive horizontal and vertical practices as well as abuse of dominance as prohibited anti-competitive practices. Section 4 of the Act regulates restrictive horizontal practices whereas section 5 regulates restrictive vertical practices. The prohibitions of both restrictive horizontal and vertical practices is based on behaviour alone; whereas the prohibition against dominance includes size or structure, and behaviour of the offending firm. ${ }^{6}$ Whether bidders collude in a horizontal or vertical format depends upon the proper legal and economic analysis, which this study reviews and offers a framework of analysis.

An assertion is made in this study that the design of the procurement process in a procompetitive manner has not been given prominence in the field of public procurement literature. This view is also made by Sanchez Graells ${ }^{7}$ who argues that the "...interplay between public procurement and competition law has traditionally been relatively asymmetrical". The research on collusive tendering is therefore important because public procurement represents large volumes of public spending and influences the economy in terms of production, and supply of goods and services. The OECD

\footnotetext{
${ }^{4}$ Campell 2011.

5 OECD 2016.

${ }^{6}$ Khumalo et al 2010.

7 Sanchez-Graells 2015.
} 
estimates that its member countries spend 15 percent of their GDP in public procurement; this percentage is estimated to be higher in developing countries. ${ }^{8}$

Public procurement is an important conduit in the delivery of public services and functioning of government. The well-functioning government and delivery of services are vital for growth, development and social welfare in any country. Large sums of money involved in public procurement makes it attractive to corruption. Stigler ${ }^{9}$ argues that an oligopolistic market provides an incentive for rival firms to form cartels. In an oligopolistic market, firms set a price and produce a quantity that maximizes industrywide economic profit; ${ }^{10}$ in essence, collusion benefits all parties to the agreement. Economic theory suggests that the incentives for bid rigging are not necessarily linked to the size of the market, but rather to the four conditions of oligopolistic competition; that is, (i)high concentration, (ii) repeated interaction, (iii) common anticompetitive strategy and (iv) transparency leading to possibility to retaliate. ${ }^{11}$ Generally, improved fairness and transparency are essential for the success of the public procurement system and assist in the detection of collusive agreements. ${ }^{12}$ The net effect of bid rigging is higher prices as well limited choices leading to the decline in the social welfare. Therefore, bid rigging or collusion is an anathema to the goals of public procurement. ${ }^{13}$

\section{Research problem}

Section 217 of the South African Constitution and procurement statutes require a public procurement system which is fair, equitable, transparent, competitive and cost-

\footnotetext{
8 OECD 2016.

9 Stigler 1964:44-61.

$1044-61$

11 Møllgaard \& Overgaard 2001.

12 Møllgaard \& Overgaard 2001.

13 Competition Commission South Africa 2017.
} 
effective. This means that a competitive public procurement system is a constitutional mandate and requirement in South Africa. However, a postulation is made that public procurement regulations and rules in South Africa are not robust enough on measures to detect and safeguard against bid-rigging and collusive behaviour. The devolution of procurement function also assumes that all organs of state have the capability and capacity to detect and prevent anticompetitive behaviour and practices. Morozov and Podkolzina ${ }^{14}$ argue that in the state sector, purchasers have no incentives to encourage healthy competition because they do not spend their own money. They, therefore, have few incentives for minimising prices and controlling the quality of the goods and services supplied; also do not take full responsibility for their actions.

Collusion is complex, multi-faceted, and a moving target which mutates. ${ }^{15}$ Trepte argues that the there are various incentive and remuneration schemes that facilitate it and these are linked to the tendering system. ${ }^{16}$ This study attempts to unravel and explain such schemes. There is a general consensus that collusion or bid rigging undermines value for money in public procurement. However, there is no one single method in tackling this challenge, which is obscure by its very nature. Multi-disciplinary or mix-use research methods are important in examining factors giving rise to collusion and are important to detect and limit incidence of collusion in public procurement. Because public procurement is multi-disciplinary in theory and practice, the research methods used to review and analyse collusion in public procurement have to be multidisciplinary as well. A singular approach is adequate in unravelling the nature and scope of collusion. Conventional public procurement regulatory methods of corruption prevention and busting which are ex post focused are inadequate in dealing with

\footnotetext{
${ }^{14}$ Morozov \& Podkolzina 2013.

15 Trepte 2005.

16 Trepte 2005.
} 
different forms of collusion. It is, therefore, important to use hybrid of research methods or instruments and institutions to diagnose and determine the extent to which regulations and administrative practices intentionally and unintentionally facilitate bid rigging in tenders.

What aggravates the challenge is that bid-rigging as anti-competitive method is complex to detect because it does not involve the public service only but extends to the business sector as well. ${ }^{17} \mathrm{He}$ contends that collusion can also be aided by corrupt administrators manipulating procurement methods and procedures; sometimes acting in cahoots with the principals, bidders or alone in the form of the bid-rigging fraud. The economic theory of the principal-agent relationship assists in understanding factors influencing behavioural and administrative practices of public procurement authorities in facilitating collusion. This theory which is fundamental in public procurement regulation is important in analysing the role and relationships between principals (elected politicians) and agents (bureaucrats or unelected public servants managing the public procurement system).$^{18}$ It is also useful in examining the relationship between the principal's objective and the agent's interest and behaviour. Schooner ${ }^{19}$ argues that principal-agent problem arises when there is a conflict of interest between the agent and the principal, which typically occurs when the agent acts solely in his/her own interests. Typically, the principal-agent problem occurs when a principal delegates an action to the agent, but the principal does not have full information about how the agent will behave, agents tend to possess more information than principals. This is because the agent has a higher skill-oriented knowledge than the principal.

\footnotetext{
17 OECD 2016.

18 Trepte 2005.

19 Schooner 2002.
} 
This economic theory assists in understanding factors influencing behavioural and administrative practices of public procurement authorities in facilitating collusion and other forms of corruption. It also creates a framework of analysing whether agents behave rationally when they make decisions pertaining to the procurement process and awarding of public contracts. This is because collusive tendering also involves bribing contracting authorities by bidders.

Yukins $^{20}$ posits that the theory is the prism to understanding the attitudes and behaviour of agents in designing tenders; their lack of accountability may lead to additional costs of public procurement. The theory can also show how the opportunities for corruption arise such manipulation of tenders, which includes lack of transparency and objectivity in specification evaluation and adjudication of tenders. This theory, though important in analysing collusion as a form of corruption, has also some limitations, especially in situations of information asymmetry, which can cause problems of moral hazard, adverse selection and poor choices. However, the theory does not explain the causes of corruption in public procurement. ${ }^{21}$ Also, this theory is inward looking on the organisation in formal regulated settings and is inadequate to analyse relationships beyond the public service. For instance, it doesn't assist much in detecting collusive agreements between the bidders in the absence of the but permeating themselves in the public procurement sphere. Also, this theory is inward looking on the organisation in formal regulated settings and is inadequate to analyse relationships beyond the public service. Evidence also suggests that sometimes corruption in public procurement can be derived from the actions of corrupt principals

\footnotetext{
20 Yukins 2010:71-79.

21 Trepte 2005.
} 
(i.e. corrupt governmental authorities), and not their subordinates (i.e. agents or bureaucrats). ${ }^{22}$

These inefficiencies cause contracting authorities to enter into contracts which do not yield value for money. In the absence of accountability, potential suppliers will be less encouraged to value public procurement and provide high quality goods and services. Persson et al argue that these situations necessitate alternative remedial measures. ${ }^{23}$ Thus Lambert-Mogiliansky and Kosenok argue that in order to be successful, collusion and corruption should be investigated conjointly. ${ }^{24}$

This study asserts that conventional public procurement regulatory methods do not focus much on induced collusion, which deals with illegal relationships between public officials and different economic agents. Through this relationship, public officials may induce collusive market sharing through their discretion to let economic agents to simultaneously readjust their bids and prices ${ }^{25}$. There has been many instances where procurement authorities have been found to have transgressed procurement methods and procedures by "... artificially narrowing the design of the procurement method with the intention of unduly favouring or disadvantaging certain economic operators"; ${ }^{26}$ such practices have been corrected by the courts.

This study, therefore, attempts to close the gap between public procurement and competition law, and contributes to literature in the development and management of competitive public markets in South Africa.

\footnotetext{
22 Persson et al. 2013: 449-471.

23 449-471.

24 Lambert-Mogiliansky \& Kosenok 2009: 95-121.

25 95-121.

26 95-121.
} 


\section{The importance and limitations of this study}

Public procurement is a multi-disciplinary field and challenges brought about by collusion are multifaceted. Therefore, the concept of collusion, its nature, scope and context within which it permeates itself in the public sector is reviewed extensively in this study. This study also analyses factors giving rise to collusion and juxtaposes the literature on how to deal with them. The role of public officials acting in cahoots with the private sector in facilitating collusion is also reviewed.

In South Africa, public procurement is devolved function to all organs of state; they can issue out tenders and manage their own in line with the procurement legislation, regulations and rules. An assertion is made in this study that not all organs of state have the capacity to ensure the well-functioning of competitive public markets and that lack of capacity undermines the legitimacy of the public procurement system. This view is supported by the Hekima Advisory ${ }^{27}$ which argues that poor regulatory environment, procurement management and the behaviour of firms give rise to collusion. The problematic area of collusion, especially in public markets is not well researched and requires are different form of analysis.

The Competition Act was amended in 2018 and on 12 July 2019, the South African President Cyril Ramaphosa published a notice in the Government Gazette to immediately bring into force certain procedural changes to the Act. There are still substantive provisions of the Act which are not yet in force; these relate to buyer power, price discrimination (both calculated to benefit small and black-owned businesses) and the "national security veto" on certain foreign investments. These provisions require the promulgation of additional regulations for them to be effectively

${ }^{27}$ Hekima Advisory 2014. 
enforced. It is, therefore, not the intention of this study to discuss the provisions of the amended Act; the focus is on the broader review of forms of collusion (e.g. cover bidding, bid suppression, bid rotation, market allocation, and market information exchange) as anathema to competition in the public sector markets and the regulatory tools that can be deployed to deal with this challenge.

\section{The interlink between public procurement, competition policies and law}

Competition is key for the well-functioning of markets, including public sector markets. ${ }^{28}$ As already stated, fairness, equity, transparency, competition and costeffectiveness are constitutionally mandated requirements in the South African public procurement system. These key principles are in sync with the 2011 UNCITRAL Model Law on Public Procurement and are important in the opening up of public procurement to public scrutiny and enhancement of the legitimacy of the public procurement system.

This study postulates that one of the reasons for collusive behaviour is that the South African economy is highly concentrated in key sectors and lacks diversity in ownership. ${ }^{29}$ Concentration has economy-wide significance. High levels of market concentration coupled with barriers to entry are a big structural problem of the South African economy. The skewness of the economy has adverse effects on the market concentration and power, production costs, price margins, scale and output as well as competitiveness. ${ }^{30}$ Economic theory teaches that highly concentrated markets where oligopolies operate give rise to collusive market sharing which results in limited

\footnotetext{
28 Schooner 2002.

29 Aghion et al 2008: 741-768.

30 741-768.
} 
competition. The economic theory teaches that the "...fewer competitors there are in the industry, the easier it is for them to establish and maintain an efficient cartel". ${ }^{31}$ Collusive tendering in public procurement is more likely to driven by forces very similar to those governing cartel formation in oligopolistic markets. ${ }^{32}$ Collusive tendering, therefore, can happen in both small and large contracts, it requires collaboration between companies in markets where there are fewer players. The hypothesis being made in this study is that the high concentration of firms in any industry is a prism to determine the probability of bid-rigging and likelihood of competitive procurement outcomes. These challenges are broadly economical but also permeate themselves in the public procurement system. Anderson et al contend that the structure, rules, and procedures governing the public procurement systems make them to be intrinsically more vulnerable to supplier collusion than are many other markets. ${ }^{33}$ In dealing with these challenges in the public sector markets in particular, the review of both public procurement and competition policies becomes critical.

One of the policy objectives of competition policy is to deter, detect, and punish collusion, whereas the objectives of public procurement are fairness, equity, transparency, competition and achieving value for money. These objectives though complementary can represent a trade-off or 'dual challenge for good governance'. ${ }^{34}$ Thus there is a need to properly regulate public markets, especially in a highly concentrated economy such as South Africa. ${ }^{35}$ Competitive procurement markets are preferred because they are designed to select the most efficient bidder and to increase value for money, thus maximising the social welfare, all other things being equal. and

\footnotetext{
31 Hazak et al 2020.

32 Dimitri et al 2006.

33 Anderson et al 2011.

34 Anderson et al 2011.

35 Aghion et al 2008: 741-768.
} 
to maximize the buyer's savings. However, oligopolies dislike competition. In order to deal with challenges of collusive tendering, fairness, non-discrimination and transparency are touted as key principles of a competitive public procurement system. Schooner ${ }^{36}$ argues that the agency theory is critical in explaining the purpose and importance of public procurement transparency, and is central in the fight against collusion and other forms corruption in public procurement.

This view is disputed by Stigler ${ }^{37}$ who points out that transparency may facilitate collusion because a cartel can promptly identify and punish defecting firms is thus one of the structural elements of procurement markets that makes the prevention of bid rigging rather tricky. ${ }^{38}$

The arguments that are generally made for giving transparency an important role in public procurement include different dimensions such as publicity for opportunities, publicity for rules (general and procurement-specific), the need to limit discretion, value for money, integrity as well verification and enforcement. ${ }^{39}$ Another criticism of transparency is that it focuses more on procurement methods and procedures which are institutional and document based. This makes transparency to be limited in dealing with multi-dimensional forms of collusion. Collusion practices are obscure, secretive and dynamic. Thus Johnston ${ }^{40}$ argues that collusive practices relate to the concept of 'chiffre noir' (black number), known in the French criminal law as the number of crimes which remain undetected by mainstream legislation, law enforcement agencies and competition authorities.

\footnotetext{
36 Schooner 2002.

37 Stigler 1964:44-61.

38 Sanchez-Graells 2018.

39 Arrowsmith et al 2000.

40 Johnston 1996: 321-335.
} 
Simkins ${ }^{41}$ argues that generally, antitrust and competition laws are directed primarily against contract, combination or conspiracy in restraint of trade and monopolising behaviour. This behaviour is meted out by dominant firms or cartels through shadow agreements aimed at setting prices and output. In South Africa, Section 4 of the Competition Act prohibits horizontal agreements between, or concerted practice by firms, or a decision by an association of firms in a horizontal relationship. The following restrictive horizontal practices are thus prohibited:

i.directly or indirectly fixing of a purchase or selling price or any other trading condition;

ii.the division of markets by allocating customers, suppliers, territories, or specific types of goods or services; or

iii.collusive tendering.

Most of the prohibited practices set out in the Act as based on the 'rule-of-reason'; whereby a conduct will only be prohibited if it has the effect of substantially preventing or lessening competition in a market, unless a party to the agreement can prove that any technological, efficiency or other pro-competitive gains resulting from that agreement outweighs that effect under section 4(1)(a) (i.e. the rule of reason test)". ${ }^{42}$ Section $4(1)(b)(i)$ contains a per se prohibition against any agreement, concerted practice or decision by an association of competitors that involves directly or indirectly fixing a purchase or selling price. ${ }^{43}$ Such conduct is outright prohibited, without an examination of actual effects on competition or permitting a showing of net efficiency. Where a firm engages in the per se unlawful practice, it is exposed to an administrative

\footnotetext{
${ }^{41}$ Simkins, 2011.

42 Katz et al 2009.

${ }^{43}$ Charter 2005.
} 
penalty for a first infringement; a penalty of up to $10 \%$ of a firm's turnover. However in 2005, the Supreme Court of Appeal in the matter between the American National Soda Ash Corporation (Ansac) and Botswana Ash (Pty) Ltd (Botash) ${ }^{44}$ made a ruling that “...in deciding whether firms have contravened section 4(1)(b) of the Competition Act by engaging in per se illegal price fixing, the Competition Tribunal ("Tribunal") must admit evidence relating to the nature, purpose and effect of the horizontal agreement or practice in question". 45 This ruling has created uncertainty regarding the treatment of agreements between competitors.

Campell argues that even though section 4 of the Act prohibits restrictive horizontal practices, its nature, scope and limits are too broad for accurate analysis. ${ }^{46}$ Further, the evaluation of effects and efficiency justifications or under section 4(1)(b) has perverse incentives to preserve the concentration of the economy; it also implies that even price fixing and market division could be excused if they promoted exports, supported small and medium companies, propped up black empowered companies. This means that an even otherwise per se violation might meet the terms for exemption. ${ }^{47}$ This study agrees with Campell's view; the public procurement literature expands the definition of collusion or bid rigging as a horizontal agreement amongst competitors not to compete on the bids they submit after being invited to tender. ${ }^{48}$ There is no defined criterion that is being followed or prescribed to investigate imperfect forms of collusion. The Competition Commission of South Africa (CCSA) also does not have a defined criteria to investigate collusion but where there are

\footnotetext{
${ }^{44}$ American Natural Soda Ash Corporation and Another $v$ Competition Commission of South Africa [2005] 3 All SA 1 (SCA).

45 Moodaliyar \& Weeks 2008.

46 Campell 2011.

47 Campell 2011.

48 OECD 2012.
} 
multiple theories of harm, it investigates hybrid cases simultaneously ${ }^{49}$. The CCSA categorises collusion into three forms, ${ }^{50}$ that is: -

i.Complementary Bid: this also known as known as 'cover', 'protective', 'courtesy', or 'shadow' bidding, occurs when some of the bidders agree to submit bids that are intended to be unsuccessful, so that another conspirator can win the contract.

ii.Bid Suppression: occurs when bidders agree to either abstain from bidding or withdraw a bid for no apparent reasons that one bidder wins the contract.

iii.Bid Rotation: this is a process whereby potential competitors agree amongst themselves to submit bids but for one of them to submit the lowest bid so that each bidder can "take turns" at winning a contract on a rotational basis.

The OECD has the market allocation schemes another form of collusion; these are agreements in which competitors divide markets allocating specific customers or types of customers, products, or territories among themselves.

i.The forms of collusion highlighted on the above are not exhaustive. This study has indicated that collusion can be complex and is not static. Other forms are as follows: Repetitive bidding. Repetitive purchases increase the chances of collusion by helping members of a bid-rigging agreement to allocate contracts among themselves and can punish a cheater by targeting the bids originally allocated to him. $^{51}$

ii.Bid Shopping: this is the practice of divulging a contractor's or subcontractor's bid to other prospective contractor(s) or subcontractor(s) before the award of a contract in order to secure a lower bid.

iii.Cover Pricing: this practice involves one or more bidders in a tender process submitting an artificially-inflated price with the aim of not securing the contract.

\footnotetext{
49 Moropene 2017.

50 Competition Commission South Africa 2017; Moropene 2017.

51 OECD 2012.
} 
iv.Subcontracting: 52 this occurs when competitors submit bids which are too expensive, bidders not meeting the tender requirements, and so forth. In this case, a bigger company wins the bid and then sub-contracts that particular contract with the non-winning bidder. ${ }^{53}$

v.Price fixing: this is an agreement among competitors to fix, raise, or adhere to price discounts at which their goods or services are sold. It is not necessary that the competitors agree to charge exactly the same price; price fixing can take many forms. In the United States of America, any agreement that restricts price competition violates the law. ${ }^{54}$ It must be noted that price fixing is a per se illegal activity and seemingly does not require an assessment of the subjective intent of the colluding parties. Anti-competitive information exchange, ${ }^{55}$ the exchanges of information between competitors of their plans regarding future output or prices is normally be considered anti-competitive by most competition authorities. ${ }^{56}$

This study concurs and argues that all forms of collusion are aimed at increasing the market share and maximising profit by lessening competition. In dealing with challenges of collusive tendering, Chassang and Ortner propose price caps (ceilings and floors) within which bids can be disqualified. ${ }^{57}$ Their contention is that this method could help reduce procurement prices by 20 percent or more. The proposal by Chassang and Ortner is useful but not sufficient as it focuses on pricing as a remedy to the challenge of bid rigging. Concomitant corruption elements such as the

\footnotetext{
52 This type of subcontracting should not be confused with Regulation 9.1 of the 2017 Preferential Procurement Regulations in South Africa, which compels "...an organ of state, in the case of selected tenders, where it is feasible to subcontract, apply compulsory subcontracting... in contracts above 30 million Rands".

${ }^{53}$ Republic of Seychelles, National Tender Board and the Procurement Oversight Unit 2016.

${ }^{54}$ United States of America: Department of Justice 2015.

${ }^{55}$ The CCSA has guidelines on the exchange of information between competitors. These are aimed at providing competitors a framework with regard to the nature, forms and effects of information exchange amongst them and its competitive effects. Information exchange between competitors, which may take various forms can either enhance or restrict competition, hence the importance of the guidelines.

56 OECD 2010.

${ }^{57}$ Chassang \& Ortner 2015.
} 
manipulation of the bid specifications, designs, industry and technical standards, and technological choices are also used as tools to undermine competition and aid certain bidders. Price alone, therefore, will be limited in dealing with these forms of collusion. It is also important to juxtapose the remedies meted out by competition authorities against remedies in the Regulation 14 of the 2017 Preferential Procurement Regulations on non-compliance pertaining to the conditions of the tender as well as the Prevention and Combating of Corrupt Activities Act (Act No. 12 of 2004) ("Corruption Act") which treats collusive tendering as corruption and provides for sentences ranging from five years to life imprisonment. Section 29 of this Act provides for the creation of a Register for Tender Defaulters by the National Treasury. Sections 12-13 of the Act allows for the endorsement of the contractor on the register only after a conviction by a court of law on charges related to corruption offence(s) in public procurement. ${ }^{58}$ Through the endorsement, contractors will be denied access or 'debarred' from participating in public contract for a period of between five and ten years. ${ }^{59}$ The purpose of the register is to lessen or prevent the risk to the government of entering into contracts and doing business with corrupt or in other ways dishonest and convicted suppliers. ${ }^{60}$ Williams and Quinot decry the effectiveness of the register in effectively debarring dishonest and convicted suppliers from participating in government contracts under the Act. ${ }^{61}$ This view is supported by Mugadza who argues that there are notable weaknesses in the implementation of the Corruption Act because of the traditional cum silo approach, poor enforcement of criminal measures

\footnotetext{
58 Williams \& Quinot 2008: $248-258$.

${ }^{59}$ Prevention and Combating of Corrupt Activities Act 12 of 2004 (South Africa) s 28(3)(a)(ii) and (iii). 60 Hjelmeng \& Søreide 2014.

61 Williams \& Quinot 2008: $248-258$.
} 
and administrative measures such as debarment as well the lack of lead anticorruption agency. ${ }^{62}$

The preferential procurement regulations also allow for the cancellation of tenders where there is non-compliance on tender conditions. These pieces of legislation create challenges of jurisdiction and defining the cause of action in dealing with collusion, and whether collusion should be dealt with as a criminal or illegal civil conduct.

In dealing with the challenge of collusion in public procurement, governments, regulatory and competition authorities have deployed methods and instruments to punish and deter colluding firms. The main methods aimed at preventing supplier collusion focus on the traditional investigative work to enforce national competition laws, including tools such as corporate leniency programmes, market inquiry, public hearings and related advocacy programmes to improve the awareness of the requirements of the Act and promote compliance. ${ }^{63}$

As already stated, the Act makes provisions for people found guilty of cartel conduct to be fined up to R500 000.00 or imprisoned for up to 10 years. With effect from May 2017, price fixing, market division and collusive tendering between actual and potential competitors can result in criminal liability for directors and managers. Various trade associations have been investigated and fined for cartel conduct on account of having exchanged competitively sensitive information. The road industry trade association was fined for facilitating exchange of competitively sensitive information which enabled its members, who were competitors, to fix prices. 
The CCSA initiated investigations in the construction industry in 2009 after it received evidence that there was pervasive collusion in sector. Given the magnitude of the cases and the need to expedite the resolution of these cases, the CCSA launched the Fast Track Settlement in February 2011. Under the Fast Track Settlement, the CCSA reached settlement with 22 firms found liable and the Tribunal confirmed all the settlement agreements between 2013 and 2015. In 2013, it fined fifteen construction firms a collective R1.5 billion for anti-competitive behaviour and collusive tendering relating to construction projects concluded between 2006 and 2011. Following the conclusion of the Fast Track Settlement, the CCSA referred to the Tribunal 19 cases against firms that opted not to settle.

The earlier case was the Competition Commission $v$ Aveng (Africa) Limited t/a Steeledale and others regarding the manufacturing and supply of reinforcing mesh products, including pipes, culverts and manholes used in the building and construction sector. The Tribunal confirmed consent order between CCSA and Aveng in that the latter through its subsidiary, Infraset, engaged in engaged in price fixing, dividing and allocating the markets and collusive tendering in the supply of concrete pipes and culverts in Gauteng, Kwazulu-Natal and the Western Cape. ${ }^{64}$ In this case and the Southern Pipeline Contractors $v$ Competition Commission, the Tribunal and Competition Appeal Court (CAC) set out a six-stage test in determining penalties; 65 this culminated in the CCSA developing guidelines consisting of consisting of six steps

\footnotetext{
64 Moropene 2017.

65 Competition Commission v Aveng (Africa) Limited t/a Steeledale and others, Reinforcing Mesh Solutions (Pty) Ltd, Vulcania Reinforcing (Pty) Limited, and BRC Mesh Reinforcing (Pty) Limited (CR057Dec09) [2012] (07 May 2012) para 133 - 154; Southern Pipeline Contractors and Another v Competition Commission (105/CAC/Dec10, 106/CAC/Dec10) [2011] ZACAC 6 (1 August 2011).
} 
in the determination of administrative penalties for prohibited practices. ${ }^{66}$ The issue of penalties is also important in the context of leniency programmes and settlements. ${ }^{67}$

Under the CCSA's corporate leniency programme (CLP), the first firm to admit to a cartel, including co-operation, the exchange and provision of information will not pay a penalty. ${ }^{68}$ In 2014 the CCSA, referred a case of bid rigging and collusion against Power Construction (West Cape) (Pty) Ltd (West Cape) and Haw and Inglis (Pty) Ltd (Haw and Inglis) to the Tribunal. ${ }^{69}$ The case against the Western Cape based companies which specialise in industrial, commercial, residential and construction sectors related to relation to the tender issued by the South African National Roads Agency (Sanral) to maintain a section of the N1 national route. The CCSA alleged that Haw and Inglis instructed West Cape to submit a bid with no intention of rendering the services but to ensure that Sanral received enough bids to award the contract in terms of its tender processes. The tender project was ultimately awarded to Haw and Inglis. Both companies admitted liability and paid an administrative penalty of R45.3 Million.

In 2017, the CCSA also charged seven companies with price fixing and collusion in a tender to provide stationery to the Free State provincial government. In 2019, furniture removal company Stuttaford Van Lines was charged with 649 counts of collusive tendering relating to hundreds of government tenders issued for furniture transportation.

\footnotetext{
${ }^{66}$ CCSA 2015.

67 Muzata et al 2012.

${ }^{68}$ Ratshisusu 2010: $587-606$.

69 Competition Commission v Power Construction (West Cape) (Pty) and Others; In re: Power Construction (West Cape) (Pty) and Another v Competition Commission (CR166Dec14) [2016] ZACT 87 (25 August 2016).
} 


\section{Policy recommendations to deal with collusive conduct in public procurement in South Africa}

Procurement measures for combating collusive conduct in public procurement should include hybrid measures such as transparency measures; ethics; criminal and civil remedies on bidders; exclusion and debarment. These measures are important but they cannot address the broader causes or prevalence of corruption in public procurement. ${ }^{70}$ While competition policy and law are critical in combating the scourge of collusive conduct in the public sector markets, an effective approach involves reforms to the public procurement systems itself. This should include pro-competitive approaches to tender design, evaluation and award procedures including performance-based standards and measures on output and outcomes. This will require appropriate legal framework, including policy body and review mechanisms as well as publicity apparatus.

One of the benefits of using the principal-agency theory to design procurement regulation is that the principal does not need to know much about the public procurement systems, it can rely on controlling the process to make sure it provides transparency and accountability and is verifiable. ${ }^{71}$ However, caution is made that fixation with correcting the principal-agent relationships often leads to over-regulation since the blame apportioned on agents, even where they are not to blame. The end result is over-regulation will have another effect of reducing efficiency and diminishing value for money.

Policy reforms should also fine-tune the interaction between anti-corruption and anticompetition measures; currently there is a lacuna with regards the jurisdiction of

70 Trepte 2005.

71 Trepte 2005. 
competition and law enforcement authorities in dealing with collusive conduct when it comes to public procurement. It is not clearly defined when and how a collusive conduct becomes a criminal offence to be dealt by law enforcement agencies or competition transgression matter to be dealt with by competition authorities. There must be a balance in the application of criminal and civil remedies in dealing collusive conduct and behaviour; this includes the role of organs of state to cancel contracts where there is maleficence as well as the specific role of the National Treasury to 'debar' and exclude bidders from any contract award procedure in the future public procurement opportunities. There is a need, therefore, to develop the 'debarment and exclusionary' system in the South African public procurement system.

Organs of state should also be capacitated to deal with competition matters in public procurement because that is a constitutional requirement. Personnel at procurement authorities may not themselves be specialists in public procurement and competition policy, this might mean that they do not have the expertise to develop and manage competitive public sector markets beyond the compliance requirements of supply chain policies. There is the need for compliance training at the outset for the purposes of familiarisation with the legislative requirements of public procurement and competition law as well the economic analysis of the industrial structure and organisation. Competence training is a necessary complement to drive more skills based training with a view to obtaining better value for money based on the ability of procurement authorities to promote strategic and outcomes based procurement.

\section{Conclusion}

This study contends that public procurement rules in South Africa are not robust enough on measures to detect and safeguard against bid-rigging and collusive conduct that can take many forms. Bid rigging is an anathema to value for money and 
competition. Thus the enforcement of competition laws requires a strong alignment with public procurement regulations to help deal with anti-competitive behaviour in the public sector markets. Key to public procurement reforms is a commitment to put in place appropriate measures and systems to strengthen procurement, competition and related anti-corruption policies, laws and systems. 


\section{Bibliography}

\section{Literature}

Aghion, P., Braun, M., and Fedderke, J. 2008. Competition and productivity growth in South Africa. Economics of Transition 16(4): 741-768.

Anderson, R.D., Kovacic, W.E., and Muller, A.C. 2011. Ensuring integrity and competition in public procurement markets: a dual challenge for good governance. In Arrowsmith, S. and Anderson, R. (Eds.). The WTO Regime on Government Procurement: Challenge and Reform. Cambridge: Cambridge University Press. Arrowsmith, S., Linarelli, J., and Wallace Jr, D. 2000. Regulating Public Procurement: National and International Perspectives. The Hague: Kluwer Law International.

Campell, J. 2011. Restrictive Horizontal Practices. In: Brassey, M. (Ed.). Competition Law. Cape Town: Juta.

Charter, C. 2005. South Africa: Price Fixing and the Per Se Rule - Quo Vadis? Mondaq. (online) Available at:

http://www.mondaq.com/southafrica/x/36344/Trade+Regulation+Practices/Price+Fixi ng+and+the+Per+Se+Rule+Quo+Vadis. (Accessed 31-12-2019).

Chassang, S. \& Ortner, J. 2015. Collusion in Auctions with Constrained Bids: Theory and Evidence from Public Procurement. Princeton University William S. Dietrich II Economic Theory Center Research Paper No. 072_2015. (online) Available at: https://ssrn.com/abstract=2683505 or http://dx.doi.org/10.2139/ssrn.2683505 (Accessed 31-12-2019).

Dimitri, N., Pacini, R., Pagnozzi, M. and Spagnolo, G., 2006. Multi-Contract Tendering and package Bidding in Procurement. In: Dimitri, N., Pacini, R., Pagnozzi, M. and Spagnolo, G. (Eds.) Handbook of Procurement - Theory and Practice for Mangers. Cambridge: Cambridge University Press. 
Hazak, A., Kerikmäe, T., and Evelin PL. 2020. Efficiency and Bid Rigging in Simultaneous Procurement Auctions under an Oligopoly. International Journal of Procurement Management (IJPM) 13(2): 199-213.

Hekima Advisory. 2014. The Role of CIDB in Limiting Construction Industry Cartels. Centre for Competition, Regulation and Economic Development, University of Johannesburg. (online) Available at:

https://static1.squarespace.com/static/52246331e4b0a46e5f1b8ce5/t/534f8d5fe4b05 3dc26f7a611/1397722463112/1400407 EDD-

\section{UJ RECBP Project+Report App12 Case+Study+-}

+Construction+and+Cartels Final.pdf (Accessed 31-12-2019).

Hjelmeng, E. and Søreide, T. 2014. Debarment in Public Procurement: Rationales and Realization. In: Racca, G.M. and Yukins, C. (Eds.) Integrity and Efficiency in Sustainable Public Contracts. Brussels: Bruylant.

Johnston, M. 1996. The search for definitions: the vitality of politics and the issue of corruption. International Social Science Journal 48(149): 321-335.

Katz, J., Marlon, D., and Chetty, D. 2017. Crossing the line - anti-competitive information sharing. (online) Available at: https://www.samra.co.za/wpcontent/uploads/2017/07/Crossing-the-Line-Information-sharing-thesis-Final-Version2.doc (Accessed 31-12-2019).

Khumalo, J., Njisane, Y., and Nqojela, P. 2010. Cover pricing in the construction industry: understanding the practice within a competition context. Presented at The Fourth Annual Competition Commission, Competition Tribunal and Mandela Institute Conference on Competition Law, Economics and Policy in South Africa, Johannesburg. 2 September 2010. (online) Available at: https://pdfs.semanticscholar.org/92d3/7733587f76e5ba05fd9af7f76dfc89b2cb74.pdf ? ga $=2.80516114 .427353076 .1587486978-1022116886.1587486978$ (Accessed 31-12-2019).

Lambert-Mogiliansky, A. and Kosenok, G. 2009. Fine-Tailored for the CartelFavouritism in Procurement. Review of Industrial Organization 35(1-2): 95-121. 
Lianos, I., and Genakos, C. 2013. Econometrics in EU Competition Law: an empirical and theoretical analysis. In: Lianos, I. and Geradin, D. (Eds.). Handbook in EU Competition Law: Enforcement and Procedure. Cheltenham, UK: Edward Elgar.

Møllgaard, H.P., and Overgaard, P.B. 2001. Market Transparency and Competition Policy. Working Papers 06-2001, Copenhagen Business School, Department of Economics. (online) Available at:

https://www.researchgate.net/publication/46524724 Market Transparency and Co mpetition Policy (Accessed 31-12-2019).

Moodaliyar, K. and Weeks, K. 2008. Characterising price fixing: A journey through the looking glass with ANSAC. South African Journal of Economic and Management Sciences 11(3): 337-353.

Moropene, N. 2017. A Review of Bid Rigging and Price-Fixing in South Africa. (online) Available at: https://ers.snapuptickets.com/ers/eventfiles/2223/presentations/Breakout Session 8 Ngoako Moropene.pdf (Accessed 3112-2019).

Morozov, I., and Podkolzina, E. 2013. Collusion Detection in Procurement Auctions. National Research University Higher School of Economics (HSE), Basic Research Program Working Papers Series: Economics WP BRP 25/EC/2013.

Mugadza, W.T. 2018. Combating Corruption in Public Procurement in Developing Countries: A Legal Analysis. PhD. North West University.

Muzata, T.G., Roberts, S. and Vilakazi, T.S. 2012. An Economic Review of Penalties and Settlements for Cartels in South Africa. Working Paper 9/2012. Centre for Competition, Regulation and Economic Development, University of Johannesburg.

OECD, 2010. Information Exchanges Between Competitor under Competition Law. Policy Roundtables. (online) Available at:

http://www.oecd.org/competition/cartels/48379006.pdf. (Accessed 31-12-2019).

OECD, 2016. Recommendation on Fighting Bid Rigging in Public Procurement. Report on Implementing the OECD Recommendation. (online) Available at: 
https://www.oecd.org/daf/competition/Fighting-bid-rigging-in-public-procurement2016-implementation-report.pdf. (Accessed 31-12-2019).

Persson, A., Rothstein, B., and Teorell, J. 2013. Why Anticorruption Reforms FailSystemic Corruption as a Collective Action Problem. Governance 26(3): 449-471.

Ratshisusu, H. 2010. Limiting Collusion in the Construction Industry: A Review of the Bid-Rigging Settlement in South Africa. Journal of Economic and Financial Sciences Special issue 1: 587-606.

Republic of Seychelles, National Tender Board and the Procurement Oversight Unit, 2016. The Basics of Bid Rigging. National Tender Board. (online) Available at: https://www.ntb.sc/news/item/30-the-basics-of-bid-rigging. (Accessed 31-12-2019).

Sanchez-Graells, A. 2015. Public Procurement: A 2015 Updated Overview of EU and National Case Law. e-Competition Bulleting Public Procurement, Art. No. 40647. (online) Available at: http://dx.doi.org/10.2139/ssrn.2613076. (Accessed 3112-2019).

Sanchez-Graells, A. 2018. Transparency and Competition in Public Procurement: A Comparative View on their Difficult Balance. In Halonen, K.M., Caranta, R., and Sanchez-Graells, A. (Eds.). Transparency in EU Procurements: Disclosure within Public Procurement and during Contract Execution. Cheltenham, UK: Edward Elgar Publishing.

Schooner, S. 2002. Desiderata: Objectives for a System of Government Contract Law. Public Procurement Law Review 11: 103-112.

Simkins, C. 2011. Restrictive Horizontal Practices. In: Brassey, M. (Ed.). Competition Law. Cape Town: Juta.

Stigler, G.J. 1964. A theory of Oligopoly. Journal of Political Economy 72(1): 44-61.

Trepte, P. 2004. Regulating procurement: Understanding the ends and means of public procurement regulation. Oxford: Oxford University Press.

Trepte, P. 2005. Transparency and Accountability as Tools for Promoting Integrity and Preventing Corruption in Procurement: Possibilities and Limitations. OECD 
Papers 5(10): 1-38. (online) Available at: https://read.oecd-

ilibrary.org/economics/transparency-and-accountability-as-tools-for-promotingintegrity-and-preventing-corruption-in-procurement oecd papers-v5-art34-en\#page2 (Accessed 31-12-2019).

United States of America: Department of Justice. 2015. Price Fixing, Bid Rigging, and Market Allocation Schemes: What they are and what to look for. Department of Justice. (online) Available at: https://www.justice.gov/atr/price-fixing-bid-rigging-andmarket-allocation-schemes. (Accessed 31-12-2019).

Williams, S. and Quinot, G. 2008. To Debar or not to Debar: When to Endorse a Contractor on the Register for Tender Defaulters. South African Law Journal 125(2): 248-258.

Yukins, C.R. 2010. A Versatile Prism: Assessing Procurement Law through the Principal Agent Model. Public Contract Law Journal 40(1): 71-79.

\section{Case law}

American Natural Soda Ash Corporation and Another v Competition Commission of South Africa [2005] 3 All SA 1 (SCA)

Competition Commission v Aveng (Africa) Limited t/a Steeledale and others, Reinforcing Mesh Solutions (Pty) Ltd, Vulcania Reinforcing (Pty) Limited, and BRC Mesh Reinforcing (Pty) Limited (CR057Dec09) [2012] (07 May 2012)

Competition Commission v Power Construction (West Cape) (Pty) and Others; In re: Power Construction (West Cape) (Pty) and Another v Competition Commission (CR166Dec14) [2016] ZACT 87 (25 August 2016)

Southern Pipeline Contractors and Another v Competition Commission (105/CAC/Dec10, 106/CAC/Dec10) [2011] ZACAC 6 (1 August 2011)

\section{Legislation, Regulations, and Proclamations}

Competition Act 89 of 1998 (South Africa)

Constitution of the Republic of South Africa, 1996

Preferential Procurement Regulations, 2017 (South Africa)

Prevention and Combating of Corrupt Activities Act 12 of 2004 (South Africa) 